UDC 77.024.48.001.42:517.518.13

V.V. Zorilo, $\mathrm{PhD}$,

Ye.Yu. Lebedeva, PhD, Assoc.Prof.,

M.O. Kozina, $\mathrm{PhD}$,

D.S. Belush

Odessa National Polytechnic University, 1 Shevchenko Ave., 65044 Odessa, Ukraine; e-mail: mashak1989@ rambler.ru

\title{
METHOD OF PHOTOMONTAGE DETECTION UNDER CONDITIONS OF LIMITATIONS ABSENCE FOR PHOTOS FALSIFICATION
}

\begin{abstract}
В.В. Зоріло, О.Ю. Лебедєва, М.О. Козіна, Д.С. Белуш. Метод виявлення фотомонтажу в умовах відсутності обмежень на використовувані при фальсифікації фотознімки. Поширене використання підроблених фотознімків в інформаційних війнах, судових справах, політиці, тощо потребує розробки нових ефективних методів виявлення фотомонтажу. Одним з них $є$ метод виявлення фотомонтажу, заснований на аналізі сингулярних чисел блоків матриці цифрового зображення. Мета: Метою роботи $є$ перевірка сфери застосування методу виявлення фотомонтажу, заснованого на аналізі сингулярних чисел блоків матриці цифрових зображень в умовах відсутності обмежень на ступінь їх стиснення. Матеріали та методи: В основі роботи розглянутого методу $є$ виявлення відмінностей між зображеннями у випадку, коли вони мають різні ступені стиснення: значення матриці нульових сингулярних чисел блоків, що відповідають чужорідній частині зображення, вирізняють цю ділянку на фоні основного зображення, що дає змогу виявити фальсифікацію. Зазначений метод було досліджено за певних обмежень, що накладалися на використані тестові фотознімки. Проведено розширений експеримент з використанням зображень, для яких відсутні обмеження на ступінь стиснення. Результати: В результаті експерименту фальсифікацію було виявлено в $44.4 \%$ випадків за умови збереження цифрового зображення після фотомонтажу в форматі без втрат, і в $53.3 \%$ випадків - при збереженні з втратами. Частіше фотомонтаж було виявлено тоді, коли різниця між коефіцієнтом якості $Q$ основного зображення і заміщуючої ділянки була більше двох.

Ключові слова: фотомонтаж, перевірка цілісності цифрового зображення, метод виявлення фотомонтажу, матриця цифрового зображення, сингулярні числа.
\end{abstract}

V.V. Zorilo, Ye.Yu. Lebedeva, M.O. Kozina, D.S. Belush. Method of photomontage detection under conditions of limitations absence for photos falsification. The widespread using of fake pictures in information wars, lawsuits, politics, etc., needs to develop new detection methods of photomontage. One of them is a method of photomontage detection based on the analysis of singular values of matrix blocks of digital images. Aim: The aim of this research is to check the application area of photomontage detection method based on analysis of singular values of matrix blocks of digital images in the absence of restrictions on the degree of their compression. Materials and Methods: The basis of this method is the detection of the differences between the images when they have different degrees of compression: values of the zero singular values matrix of blocks corresponding to foreign part of image. We distinguish this area on the background of the main image, that allows to detect falsification. The mentioned method was investigated under certain restrictions imposed on the used test photos. An advanced experiment with images was held, for which there are no restrictions on the degree of compression. Results: The falsification was detected in $44.4 \%$ of cases in experimental study while saving the digital image after photomontage in lossless format, and in 53.3\% of cases when saving the losses. Montage was detected most often when the difference between the quality factor $Q$ of the main image and the replacing area was more than two.

Keywords: photomontage, digital image integrity checking, photomontage detection method, digital image matrix, singular numbers.

Introduction. Photomontage story begins long before the creation of modern graphic editors. With the first pictures people began to experiment - to combine the objects and scenes of different photos. Earlier to identify the photofake was easier by means of expert visual evaluation. Today, information technology in the area of computer graphic allows execute montage so that even experts are not able to detect it. Therefore, the development of photomontage detection methods that effective without expert is important and urgent today. In this paper as the montages we will understand the result and the process of images creating composed of several parts of different photos.

Scientists around the world work over photomontage detection. Note, the existing methods have their areas of application, its advantages and shortcomings.

Now actively the methods of digital image (DI) analysis are developing, grounded on the general approach to the analysis of the state and operation of information systems technology [1]. One is a method of photomontage detecting, based on the analysis of singular numbers of the matrix DI units.

DOI 10.15276/opu.2.49.2016.12

(C) 2016 The Authors. This is an open access article under the CC BY license (http://creativecommons.org/licenses/by/4.0/). 
The work of this method is to identify the differences between the images when they have different degrees of compression. There are [2] formal differences established between DI in lossy and lossless format and DI in lossy formats with different quality factor.

Quality factor $(Q)$ for lossy format JPEG determines the measure of photography compression. In this research it meets the standard of graphics editor Adobe Photoshop, according to which $Q$ takes a value between $0 . . .12$ where more value $Q$ corresponds to less compression of the image.

The mentioned method was investigated under certain limitations of used photos. In [2] it was justified the use of images with $Q \geq 8$ (for images compressed with a lower value of $Q$, the artifacts of compression appear that violate the stability of perception).

However, there are situations when images used in montages have low quality. In this regard, there is a need to clarify the application area of this method.

The aim of this research is to check the application area of photomontage detection method based on analysis of singular values of matrix blocks of digital images in the absence of restrictions on the degree of their compression.

Materials and Methods. The main instrument for the analysis of digital images for this method is the so-called zero singular numbers matrix of blocks (ZSNMB). Each element of this matrix corresponds to the block $8 \times 8$ matrix of digital image brightness, takes values from 0 to 8 and means number of zero singular numbers in the block $[1,2]$.

For DI in lossless format ZSNMB consists mostly of zeros. When compressing with the highest quality it is possible blotches of units, sometimes twos. With increasing DI compression the ZSNMB elements can take values from 0 to 8 , which are caused by linear dependence row/columns of matrix [1]. Consider the example of this method (Fig. 1). In the image of the lake was inserted the boat with rowing.

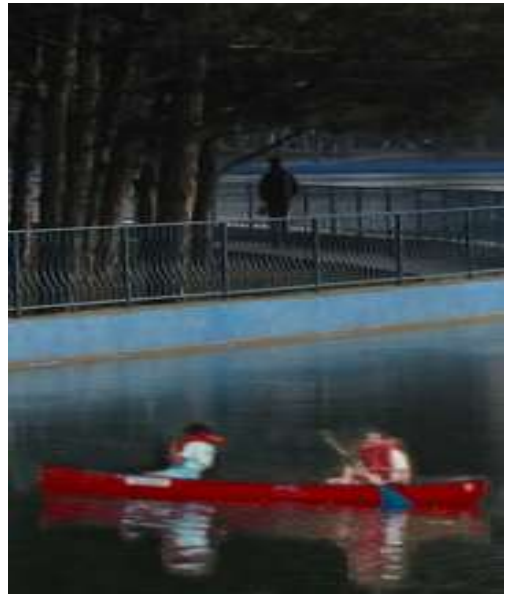

$a$

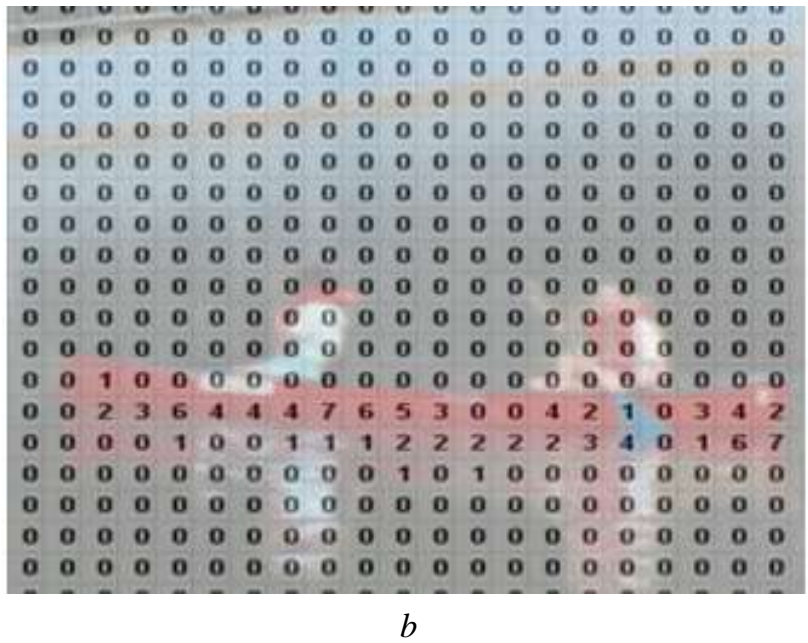

$b$

Fig. 1. Photomontage (a) and ZSNMB of falsified DI (b)

As we can see, the ZSNMB value corresponding to foreign parts of images distinguish this area against the main image that allows you to detect the falsification.

Carry out an advanced experiment with images, for which there are no restrictions on the degree of compression. For the experiment there are 30 digital images in a lossless format of resource [3] used (traditional base of digital images when tested algorithms and methods).

In the image that saved before the montage in JPEG format with quality $n$ (the main image), we insert a different part of the image (by replacing area) that has been saved in JPEG format with quality $1,2, \ldots,(n-1)$, where $\mathrm{n}$ takes the value from 1 to 10 . The results are saved in lossless format (results typical for most photographic fakes are presented in Table 1) and in the lossy format JPEG with the same value of $Q$, as the main image (results typical for most received photo fakes are presented in Table 2). 
Results of the experiment with the saving of photomontage in lossless format

\begin{tabular}{c|c|c|c|c|c|c|c|c|c|c|}
\hline & & & & & & & & & \\
\hline
\end{tabular}

Table 2

Results of the experiment with saving of photomontage in the losses format

\begin{tabular}{c|c|c|c|c|c|c|c|c|c|c}
\hline & 10 & 9 & 8 & 7 & 6 & 5 & 4 & 3 & 2 & 1 \\
\hline
\end{tabular}

In these tables, we took the following notation: $N$ (negative) - photomontage not found; $P$ (positive) - photomontage found; "_- - experiment was not carried out.

Results and Discussion. In the experiment the falsification was detected in $44.4 \%$ of cases when saving digital image after of photomontage in a lossless format, and in $53.3 \%$ of cases — when saving the digital image with losses. More often montage was detected when the difference between the $Q$ factor of the main image and replacing area was more than two. However, reveal a pattern that generally would make recommendations concerning area of application in this method is not possible.

Number of photomontage gaps if available — a very important indicator of the method effectiveness. The results showed that this method can not be recommended for widespread use to verify the integrity of digital images. However, it can be used in complex information security system or in combination with other methods of checking the integrity of digital images.

In the future the efficiency of this method we will research the impact of the block structure of digital images (background, contour) on properties its ZSNMB in the absence of restrictions on use for the photographs falsification. This, say the authors, will help monitor the uncharacteristic for integrated DI changes of singular numbers, which in turn will improve the process of fakes identifying.

This scientific work made it possible to critically assess the earlier developed method of detecting photomontage in conditions where there are no restrictions on use for the photographs falsification that are useful for the further development of an complex information security system. 


\section{Література}

1. Кобозева, А.А. Основы общего подхода к решению проблемы обнаружения фальсификации цифрового сигнала / А.А. Кобозева // Електромашинобудування та електрообладнання. — 2009. — Вип. 72. - С. 35-41.

2. Зорило, В.В. Анализ особенностей сингулярных чисел матриц цифровых изображений при разных степенях сжатия для выявления фотомонтажа / В.В. Зорило, А.А. Кобозева // Захист інформації. - 2010. - Т. 12, № 3(48). - С. 34-40.

3. NRCS Photo Gallery [Електронний ресурс] / United States Department of Agriculture. Washington, USA. — Режим доступу: http://photogallery.nrcs.usda.gov (Дата звернення: 26.07.2012).

\section{References}

1. Kobozeva, A.A. (2009). Foundations of general approach to a problem of detection of digital signal forgery. Electrical Machine-Building and Electrical Equipment, 72, 35-41.

2. Zorilo, V.V., \& Kobzeva, A.A. (2010). Analysis of features of singular values of the matrix of digital images at different compression ratios for the image forgery detection. Ukrainian Information Security Research Journal, 12(3), 34-40.

3. USDA: United States Department of Agriculture (n.d.). NRCS Photo Gallery. Retrieved from http://photogallery.nrcs.usda.gov/res/sites/photogallery/ 